\title{
Bir Tıp Fakültesinde İntörn Hekimlerin, COVID-19 Hastalarını Muayene ve Takip İçin Hazır Bulunuşluk Algıları ve Pandemi Sürecinde Eğitimlerine İlişkin Beklentileri
}

\section{Faculty of Medicine Interns' Perceptions of Readiness for Examination and Following COVID- 19 Patients and Their Expectations Regarding their Education during the Pandemic Period}

\author{
${ }^{1}$ Türkkan ÖZTÜRK KAYGUSUZ \\ ${ }^{1}$ Fırat Üniversitesi, Tıp Fakültesi/ Tıp eğitimi Anabilim Dalı, Elazığ-TÜRKIYYE \\ Türkkan Öztürk Kaygusuz: https://orci.org/0000-0002-41515903
}

\section{ÖZ}

Amaç: Bu çalışmada bir tıp fakültesi intörn hekimlerinin, COVID-19 hastalarını takip için gerekli bilgi ve becerilerde kendilerine yönelik yeterlik algılarının ve pandemi döneminde eğitimlerine ilişkin beklentilerinin belirlenmesi hedeflenmiștir.

Materyal ve Metot: Kesitsel çalışmada, çalışmaya katılan $117(\% 73,5)$ intörn hekimin, anket yanıtları değerlendirilmiştir. Anket, Ulusal Çekirdek Eğitim Programında yer alan temel tıbbi yeterlikler dikkate alınarak dijital form üzerinden hazırlanmış ve WhatsApp grubunda tüm intörnlere ulaştırılmıştır.

Bulgular: COVID-19 ön tanıs1 alan bir hastada, intörn hekimlerin \%65'i sistemik fizik muayene yapabileceklerini bildirmișlerdir. İntörnlerin el hijyeni, kișisel koruyucu ekipmanları kurallarına uygun olarak kullanmayı bilme konusunda yeterlik algıları oldukça iyi iken, bulaşıcı hastalıklarda uygulanması gereken izolasyon yöntemlerini (\% 58,3 ), alet ve ortamlar için uygun olan dezenfeksiyon, sterilizasyon yöntemlerini $(\% 27,4)$, hasta odalarının ve eşyalarının temizlik kurallarını $(\% 23,9)$ bilme konusundaki yeterlik algıları oldukça düşüktü. İntörn hekimlerin \% 60,7'si, COVID-19 salgını sırasında özellikle mezuniyetlerinin gecikmemesi ve COVID-19 hastalarının takip edilmediği servislerde klinik eğitimlerine devam etmeyi istemekteydi.

Sonuç: Tıp eğitiminde, bulaşıcı hastalıklardan korunma yöntemlerinin öneminin kavranması için teorik ve pratik eğitim uygulamalarının artırılması gerektiği düşünülmüştür.

Anahtar Kelimeler: Beceri, COVID-19, intörn hekim, tıp eğitimi, yeterlik

\section{ABSTRACT}

Objective: Determining the perceptions of competence of a faculty of medicine interns in terms of knowledge and skills to follow COVID-19 patients and their expectations regarding their education during the pandemic period. Materials and Methods: In cross-sectional study, the answers of 117 (73.5\%) participant interns to the questionnaire were evaluated. The questionnaire were prepared on a digital form, taking into account the basic medical competencies mentioned in the National Core Education Program and these were delivered to interns through the WhatsApp group.

Results: $65 \%$ of interns reported that they could perform systemic physical examination in a patient with prediagnosis of COVID-19. While the interns' perception of competence in using personal protective equipment is quite good, the level of knowledge of isolation methods $(58.3 \%)$, disinfection and sterilization methods $(27.4 \%)$ that are suitable for tools and environments and the cleaning rules of patient rooms and belongings $(23.9 \%)$ is quite low. The $60.7 \%$ of the interns wanted to continue their clinical training during the COVID-19 epidemic, especially in the services where COVID-19 patients were not followed thus their graduation would not be delayed.

Conclusion: In medical education, it is thought that the prevention methods of infectious diseases should be emphasized in theoretical and practical training applications should be increased.

Keywords: Competence, COVID-19, interns, medical education, skills

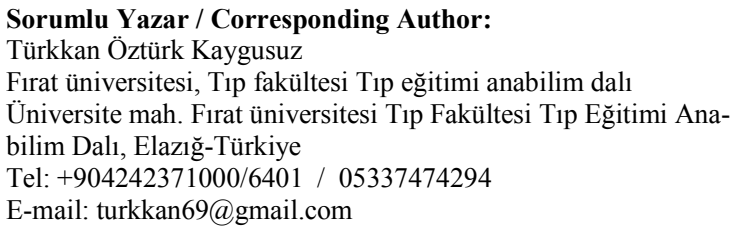

Atıf / Cited: Öztürk Kaygusuz T. Bir Tıp Fakültesinde İntörn Hekimlerin, COVID-19 Hastalarını Muayene ve Takip İçin Hazır Bulunusluk Algıları ve Pandemi Sürecinde Eğitimlerine İlişkin Beklentileri. Online Türk Sağllk Bilimleri Dergisi 2021;6(3):353-360. doi: 10.26453 otjhs. 828359 


\section{GİRIŞ}

İlk olarak Aralık 2019 tarihinde Çin'in Wuhan bölgesinde ortaya çıkan SARS-CoV-2'nin sebep olduğu COVID-19 pandemisi, birçok ülkede eğitime ara verilmesine neden olmuştur. ${ }^{1} \mathrm{Bu}$ süreçte tıp eğitimine ara verilmesi veya devam ettirilmesi ülkelere göre değişkenlik göstermiştir. $^{2}$

Pandemi sürecinde çok sayıda hekim ve sağlık çalışanının enfekte olması durumunda sağlık hizmetlerinin yetersiz kalabileceği endişesi ile tıp öğrencilerinin eğitimlerine devam etmesi gerekliliği gündeme gelmiştir. ${ }^{2-4}$ Amerikan tıp okulları birliği (AAMC), tıp öğrencilerinin henüz doktor olmadıkları için işgücüne ihtiyaç olmadığı sürece hasta takibi yapmamalarını şiddetle önermiştir. ${ }^{5,6}$ İngiltere'de genel tıp okulları konseyi (GMS) tarafindan, acilen hekim ihtiyacı olabileceği endişesi ile eğitimlerinin mevcut haliyle mezuniyet için yeterli yetkinlikleri kazandırdığı, bu nedenle intörnlerin hızla işgücüne katılabilecekleri belirtilmiştir. ${ }^{7,8}$

Fakültemizde mezuniyetlerine dört ay kala COVID19 pandemisinin gelişmesi nedeniyle intörn hekimlerin pandeminin seyrine göre COVID-19 hastalar1nın takip edildiği poliklinik ve klinik ortamlarında çalışmaları gerekebilecektir. Ayrıca bu öğrencilerin salgının seyrine göre mezuniyetlerinden sonra da bu hastaların takibini yapmaları kaçınılmaz olacaktır.

Bu çalışma, intörn hekimlerin COVID-19 hastalarının takibine yönelik bilgi ve becerilerde kendilerine yönelik yeterlik algılarını ve pandemi döneminde eğitimlerine ilişkin beklentilerini saptayarak bu sonuçların COVID-19 eğitim programının hazırlanmasına temel oluşturması amacıyla planlanmıştır.

\section{MATERYAL VE METOT}

Bu kesitsel çalışma 2019-2020 eğitim-öğretim döneminde eğitim alan bir tıp fakültesinin intörn hekimleri arasında yapılan anket sonuçlarının değerlendirilmesidir. Çalışma, 30 Nisan-15 Mayıs 2020 aralığında yapılmıştır. Çalışmada 159 intörn hekimin hepsine ulaşılması hedeflenmiş, ancak ankete 117 $(\% 73,5)$ intörn hekim yanıt vermiştir. Google form üzerinden hazırlanan anket formu, sinıf temsilcisi aracılığıyla intörn hekimlerin WhatsApp grubuna yönlendirilmiş ve çalışmaya katılmaya gönüllü olanlardan formları dijital ortamda doldurmaları istenmiştir. Yirmi altı sorudan oluşan anket formu Ulusal Çekirdek Eğitim Programı (UÇEP)'nda yer alan temel tıbbi yeterlikler, COVID-19 hastası takip ederken gerekebilecek yeterlikler dikkate alınarak hazırlanmıştır. ${ }^{9}$ COVID-19 hastası takip ederken gereke- bilecek yeterlikler, enfeksiyon hastalıkları uzmanının görüşü alınarak hazırlanmıştır. Anket formunun dört sorusu ile bazı sosyodemografik özellikleri, altı soru ile pandemi döneminde eğitimlerine ilişkin beklentileri ve son 11 soru ile de COVID-19 hastalarında gerekebilecek temel tıbbi beceri ve bilgileri aç1sından yeterlik algıları sorgulanmıştır. Çalışma, Fırat Üniversitesi Girişimsel Olmayan Etik Kurulundan etik onay (Tarih:29.04.2020, karar no: 2020/0702) ve Sağlık Bakanlığı'ndan izin alındıktan sonra gerçekleştirilmiştir. Çalışma Helsinki Deklarasyonu prensipleri 'ne uygun olarak yapılmıştır.

Istatistiksel Analizler: Verilerin istatistiksel analizi IBM SPSS 22,0 istatistik paket programında yapılmıştır. Veriler, frekans ve yüzde (\%) olarak tanımlanmış, katılımcıların yaşı, ortalama ve standart sapma olarak tanımlanmıştır.

\section{BULGULAR}

Çalışmaya 117 intörn hekim katılmıştır. Yaş ortala-

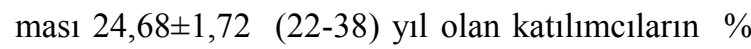
50,4 'ü $(\mathrm{n}=59)$ erkektir. İntörn hekimlerin \%90,6's1 sosyal izolasyon tedbiri gereği okullara ara verilen dönemi ailesi ile birlikte geçirdiğini ifade etmiştir. İntörn hekimlerin COVID-19 hastasında gerekebilecek temel tıbbi beceri ve bilgiler açısından kendilerinin yeterlik algılarına yönelik sorulara verdikleri cevaplar Tablo 1'de verilmiştir. Katılımcıların \% 84,6's1 COVID-19 olduğu düşünülen bir hastadan hikaye alabileceğini, \%65'i sistemik fizik muayene yapabileceğini; \%58,3'ü bulaşıcı hastalıklarda uygulanması gereken izolasyon yöntemlerini, \% 27,4'ü alet ve ortamlar için uygun olan dezenfeksiyon, sterilizasyon yöntemlerini, \%15,4’ü epikriz yazmayı bildiğini belirtmiştir.

İntörn hekimler, tıbbi kişisel koruyucu ekipmanlardan en çok eldiven giyme/çıkarma ve maske takma/çıkarma kurallarını bildiğini belirtirken en az koruyucu tulum giyme/çıkarma kurallarını bildiğini, \%11,1'i ise kişisel koruyucu ekipman giyme kurallarının hiçbirini bilmediğini ifade etmiştir. İntörn hekimler, hastanenin bilişim sistemine en çok radyolojik görüntülere ulaşabilme ve tetkik isteme konusunda; en az olarak da hasta için gerekli malzeme ve ilaç istemi yapabilme konularında hâkim olduklarını belirtmiştir.

Çalışmada temizlik ve hijyen kurallarını bildiğini ifade eden intörn hekim yüzdeleri Şekil 1 'de verilmiştir. Hijyen prosedürlerinden en çok el yıkama ve el dezenfektanı kullanma yöntemlerini bildiklerini; en az oranda da temizlik personeline anlata- 
Tablo1. İntörn hekimlerin COVID-19 hastasında gerekebilecek temel tıbbi beceri ve bilgiler açısından yeterlik algiları.

\begin{tabular}{|c|c|c|c|c|}
\hline \multirow{3}{*}{ ANKET SORULARI } & \multicolumn{4}{|c|}{ Yanıtların Dağılımı } \\
\hline & \multicolumn{2}{|c|}{ Evet } & \multicolumn{2}{|c|}{ Hayır } \\
\hline & $\mathbf{N}$ & $\%$ & $\mathbf{N}$ & $\%$ \\
\hline COVID-19 olduğu düşünülen bir hastadan öykü alabilir misiniz? & 99 & 84,6 & 18 & 15,4 \\
\hline COVID-19 olduğu düşünülen bir hastaya sistemik fizik muayene yapabilir & 76 & 65 & 41 & 35 \\
\hline $\begin{array}{l}\text { Bulaşıcı hastalıklarda uygulanması gereken izolasyon yöntemlerini (Temas } \\
\text { izolasyonu, damlacık izolasyonu, solunum izolasyonu) ve nasıl uygulandığını } \\
\text { biliyor musunuz? }\end{array}$ & 63 & 53,8 & 54 & 46,2 \\
\hline Alet ve ortamlar için uygun olan dezenfeksiyon, sterilizasyon yöntemlerini & 32 & 27,4 & 85 & 72,6 \\
\hline Epikriz yazmayı biliyor musunuz? & 18 & 15,4 & 99 & 84,6 \\
\hline \multicolumn{5}{|c|}{ COVID-19 hastasına tanı koymada yardımcı olabilecek aşağıdaki uygulamalardan hangisini yapabilirsiniz?* } \\
\hline Akciğer grafisini yorumlayabilirim & 90 & 76,9 & 27 & 23,1 \\
\hline İdrar kültürü alabilirim & 86 & 73,5 & 31 & 26,5 \\
\hline Kan kültürü alabilirim & 71 & 60,7 & 46 & 39,3 \\
\hline Boğaz kültürü alabilirim & 63 & 53,8 & 54 & 46,2 \\
\hline Nazofaringeal kültür ve sürüntü örneği alabilirim & 54 & 46,2 & 63 & 53,8 \\
\hline Hiçbiri & 7 & 6 & 110 & 94 \\
\hline \multicolumn{5}{|c|}{ Kişisel koruyucu ekipmanların hangisini kurallarına uygun olarak kullanmayı biliyorsunuz?* } \\
\hline Eldiven giyme ve çıkarma & 103 & 88 & 14 & 12 \\
\hline Maske takma ve çıkarma & 102 & 87,2 & 15 & 12,8 \\
\hline Bone takma ve çıkarma & 65 & 55,6 & 52 & 44,4 \\
\hline Koruyucu önlük giyme ve çıkarma & 62 & 53 & 55 & 47 \\
\hline Koruyucu gözlük, yüz siperi kullanma ve çıkarma & 60 & 51,3 & 57 & 48,7 \\
\hline Ayak koruyucu ( galoş) giyme ve çıkarma & 57 & 48,7 & 60 & 51,3 \\
\hline Koruyucu tulum giyme ve çıkarma & 30 & 25,6 & 87 & 74,4 \\
\hline Hiçbiri & 13 & 11,1 & 104 & 88,9 \\
\hline \multicolumn{5}{|l|}{ Hastanenin bilişim sistemine hangi konularda hakimsiniz? * } \\
\hline Radyolojik görüntülere ulaşabilirim & 112 & 95,7 & 5 & 4,3 \\
\hline Tetkik istemeyi biliyorum & 111 & 94,9 & 6 & 5,1 \\
\hline Hasta için gerekli malzeme, ilaç istemi yapabilirim & 37 & 31,6 & 80 & 68,4 \\
\hline
\end{tabular}

*: Soruya birden fazla cevap verilmiştir.

bilmek ve onları kontrol edebilmek için hasta odalarının ve eşyalarının (çarşaf, battaniye) temizlik kurallarını bilmediklerini ifade etmişlerdir.

İntörn hekimlerin temel tıbbi becerilerden hangilerini yapabilirsiniz sorusuna verdikleri cevaplar Şekil 2'de sunulmuştur. Birinci sırada kan şekeri bakabileceklerini, EKG çekip kabaca yorumlayabile- ceklerini ve idrar sondası takabileceklerini; ikinci sırada ise kan gazı alabileceklerini, tansiyon ölçebileceklerini ve kardiyopulmoner resusitasyon yapabileceklerini, en az oranda da tedavi için gerekli flakon, ampul, serum seti hazırlama, entübasyon yapabilme ve intravenöz (IV) mayi-ilaç teda-

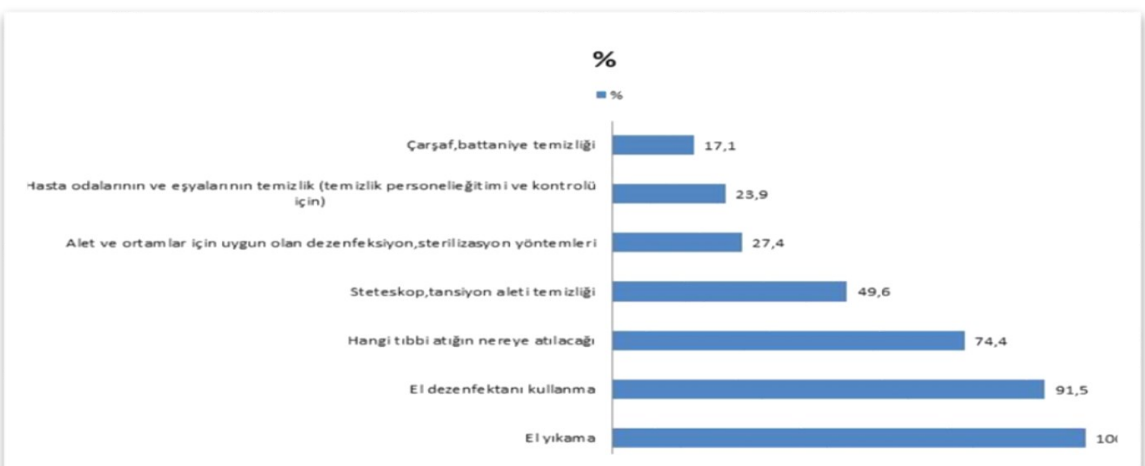

Şekil 1.Temizlik ve hijyen kurallarını bildiğini ifade eden intörn hekim yüzdeleri. 
visi uygulayabilme becerilerinin olduğunu belirtmişlerdir.

İntörn hekimlerin salgın sürecinde eğitimleri ile ilgili düşüncelerine yönelik sorulan sorulara verildikleri cevaplar Tablo 2' de verilmiştir. Katılımcıların \% 60,7 'si salgın sırasında klinik eğitimlerine devam etmek istediğini, ancak bunların da \%67,6's1 COVID-19 hastalarının takibinin yapılmadığı birimlerde eğitimlerine devam etmek istediklerini belirtmişlerdir. Çalışmaya katılan intörn hekimlerin \% 85,9'u mezuniyetlerinin gecikmemesi için kinik eğitimlerine devam etmek istediklerini ifade etmişler-

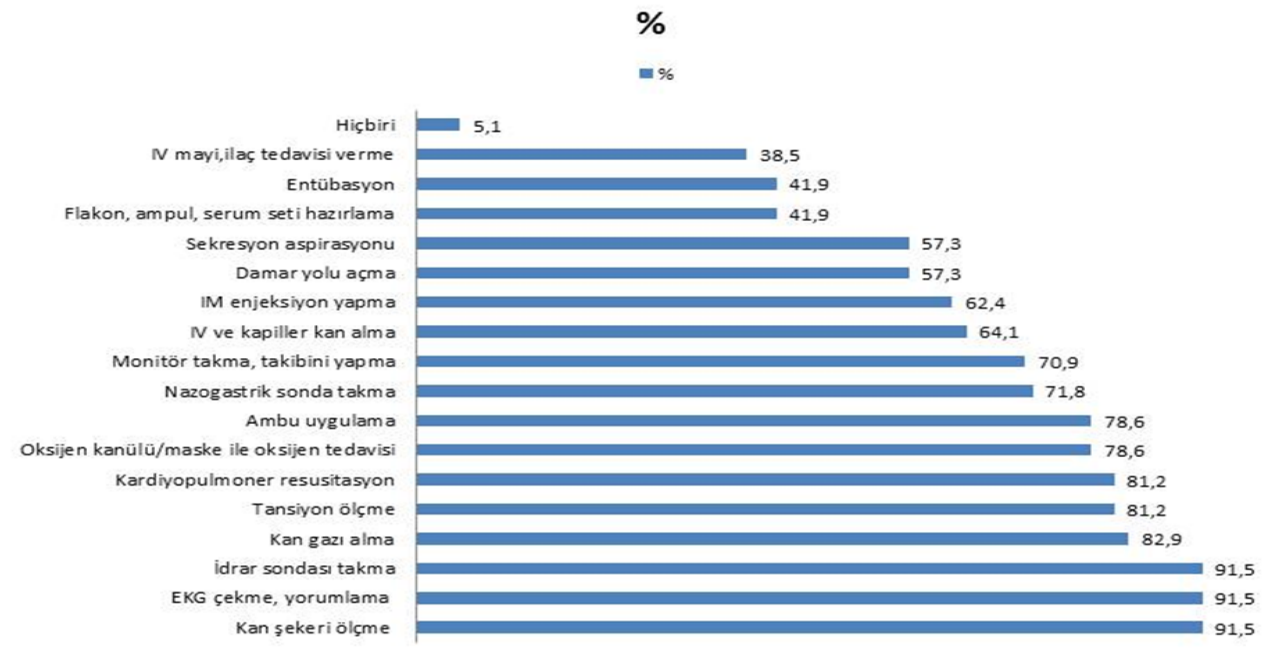

Şekil 2.Temel tıbbi becerileri yapabildiğini ifade eden intörn hekim yüzdeleri.

dir. İntörn hekimlerin \%39,3’ü (n=46) salgın sırasında klinik eğitimlerine devam etmek istemediğini, bunun nedeni olarak da en çok $(\% 87)$ virüsü ailesine ve çevresine taşıma endişesi yaşadıklarını $(\% 45,7)$ ve salgın sırasında eğitimin öncelikli olmadığını düşündüklerini bildirmişlerdir. COVID-19 nedeniyle görev almanız istense hangi birimde çalışmak istersiniz sorusuna katılımcıların \%20,5'i hiçbir birimde çalışmak istemediğini belirtirken, diğer katılımcılar birinci sırada serviste, ikinci sırada poliklinikte ve üçüncü sırada taburcu olmuş hastaların takibinde çalışmak istediklerini ifade etmişlerdir. Çalışmaya katılan intörn hekimlerin \%21,4'ü eğitimlerine des- tek verildiği takdirde COVID-19 hastasını takip edebileceğini belirtmiştir.

Çalışmaya katılan intörn hekimlerin \%85,9'u mezuniyetlerinin gecikmemesi için kinik eğitimlerine devam etmek istediklerini ifade etmişlerdir. İntörn hekimlerin \%39,3'ü (n=46) salgın sırasında klinik eğitimlerine devam etmek istemediğini, bunun nedeni olarak da en çok $(\% 87)$ virüsü ailesine ve çevresine taşıma endişesi yaşadıklarını $(\% 45,7)$ ve salgın sırasında eğitimin öncelikli olmadığını düşündüklerini bildirmişlerdir. COVID-19 nedeniyle görev almanız istense hangi birimde çalışmak istersiniz sorusuna katılımcıların \%20,5'i hiçbir birimde çalışmak iste-

Tablo 2. İntörn hekimlerin pandemi döneminde eğitimlerine ilişkin beklentileri.

\begin{tabular}{|c|c|c|c|c|}
\hline \multirow{3}{*}{ ANKET SORULARI } & \multicolumn{4}{|c|}{ Yanıtların Dağılımı } \\
\hline & \multicolumn{2}{|c|}{ Evet } & \multicolumn{2}{|c|}{ Hayır } \\
\hline & $\mathbf{n}$ & $\%$ & $\mathbf{n}$ & $\%$ \\
\hline COVID-19 salgını sırasında klinik eğitiminize devam etmek istiyor musunuz? & 71 & 60,7 & 46 & 39,3 \\
\hline \multicolumn{5}{|c|}{ Klinik eğitiminize devam etmek istiyorsanız bunu hangi birimde yapmak istersiniz? $(\mathrm{n}=71)$} \\
\hline COVID-19 hastalarının takibi yapılmayan birimlerde & 48 & 67,6 & 23 & 32,4 \\
\hline COVID-19 hastalarının takibinde & 5 & 7 & 66 & 93 \\
\hline Fark etmez, her ikisi de olabilir & 18 & 25,4 & 53 & 74,6 \\
\hline \multicolumn{5}{|l|}{ Kinik eğitiminize neden devam etmek istiyorsunuz?* $(n=71)$} \\
\hline Mezuniyetimin gecikmemesi için & 61 & 85,9 & 56 & 14,1 \\
\hline $\begin{array}{l}\text { Şimdi ve mezuniyet sonrasında gerekeceği için COVID-19 hastalarını takip edip } \\
\text { öğrenmeliyim }\end{array}$ & 28 & 39,4 & 89 & 66,6 \\
\hline Ben bir doktorum, böyle zamanlarda çalışmam gerek & 28 & 39,4 & 89 & 66,6 \\
\hline Salgın döneminde benim yardımıma ihtiyaç olabileceği için & 13 & 18,3 & 104 & 81,7 \\
\hline
\end{tabular}

*: Soruya birden fazla cevap verilmiştir. 
Tablo 2. Devam.

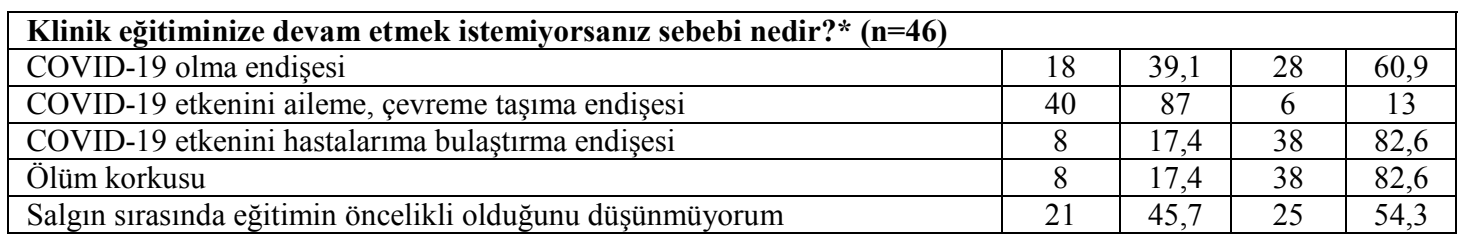

COVID-19 nedeniyle görev almanız istense (gönüllü veya mecburi) hangi birimde çalışmak istersiniz? $(\mathbf{n}=117)$

\begin{tabular}{|c|c|c|c|c|}
\hline Servis & 32 & 27,4 & 85 & 72,6 \\
\hline Poliklinik & 22 & 18,8 & 95 & 81,2 \\
\hline Taburcu olmuș hastaların takibini yapmak & 13 & 11,1 & 104 & 88,9 \\
\hline Yoğun bakım & 11 & 9,4 & 106 & 90,6 \\
\hline Hasta ve yakınlarının eğitimini yapmak & 8 & 6,8 & 109 & 93,2 \\
\hline Laboratuvar hizmetleri & 4 & 3,4 & 113 & 96,6 \\
\hline Sekretarya işlemleri gibi geri plan hizmetlerinde & 2 & 1,7 & 115 & 98,3 \\
\hline Tetkiklerin yazılması, istenmesi, işlenmesi gibi yan işlerde & 1 & 0,9 & 116 & 99,1 \\
\hline Kan alma, tedavi yapma gibi hizmetlerde & - & - & - & - \\
\hline Hiçbiri & 24 & 20,5 & 93 & 79,5 \\
\hline \multicolumn{5}{|c|}{ COVID-19 hastalarını takip etmeniz istense bunu hangi durumda yapmak istersiniz? } \\
\hline Eğitimime destek verilirse tek başıma yapabilirim & 25 & 21,4 & 92 & 78,6 \\
\hline Asistan veya öğretim üyesi gözetiminde yapmak isterim & 56 & 47,9 & 61 & 52,1 \\
\hline Asistan veya öğretim üyesine yardımcı olarak yapmak isterim & 36 & 30,8 & 81 & 69,2 \\
\hline Kan alma, tedavi yapma gibi hizmetlere yardımcı olarak & - & - & - & - \\
\hline
\end{tabular}

*: Soruya birden fazla cevap verilmiştir.

mediğini belirtirken, diğer katılımcılar birinci sırada serviste, ikinci sırada poliklinikte ve üçüncü sırada taburcu olmuş hastaların takibinde çalışmak istediklerini ifade etmişlerdir. Çalışmaya katılan intörn hekimlerin \%21,4'ü eğitimlerine destek verildiği takdirde COVID-19 hastasını takip edebileceğini belirtmiştir.

\section{TARTIŞMA VE SONUÇ}

Çalışmada intörn hekimlerin \%60,7'si COVID-19 salgını sırasında klinik eğitimlerine devam etmek istediğini bildirmiş, bunların da büyük kısmı COVID-19 hastalarının takibinin yapılmadığ lerde eğitimlerine devam etmek istediklerini belirtmiştir. İntörn hekimlerin \%85,9'u mezuniyetlerinin gecikmemesi, \%39,4'ü COVID-19 hastalarının takibini öğrenmek, \%39,4'ü kendilerini hekim olarak gördüklerini, böyle durumlarda çalışmaları gerektiği için eğitimlerine devam etmek istediğini ifade etmiştir. Bu sonuçlar intörnlerin eğitimlerini tamamlayarak ve yeterliliklerini sağlayarak mezuniyetlerinin gecikmesini istemedikleri şeklinde yorumlanmıştır. İngiltere' de tıp fakültesinde okuyan öğrencilerin de salgın sırasında sağlık sisteminde görev almak istedikleri bildirilmiştir. ${ }^{4}$

Salgın hastalıkların, sağlık öğrencilerini psikolojik yönden olumsuz etkileyerek onlarda kaygı ve endişeye neden olduğu bilinmektedir. $\mathrm{Bu}$ endişenin en büyük kaynağının hastalığı aile ve çevresine bulaştırma korkusu olduğu bildirilmektedir. ${ }^{10-12}$ Çalışma- mızda da salgın sırasında eğitimlerine devam etmek istemeyen intörn hekimler, en çok ailesine, çevresine virüsü taşıma ve kendisinin de hasta olma endişesini dile getirmişlerdir.

İntörn hekimlerin \%78,7'si asistan veya öğretim üyesi gözetiminde ve onlara yardımcı olarak COVID-19 hastalarını takip etmek istediklerini bildirmişlerdir. Katılımcıların bu salgın döneminde özellikle hasta takibi yapmak istedikleri, sekretarya işlemleri gibi geri plan hizmetlerde, laboratuvar hizmetleri, tetkiklerin yazılması, istenmesi, işlenmesi gibi yan işlerde görev almak istemedikleri anlaşılmıştır. Nitekim reçete yazamadıkları için intörn hekimlerin bir doktorun yardımcısı olarak hasta takibinde yer almaları, yeterlikleri dâhilinde sağlık hizmetinde görev yapmaları önerilmektedir. $^{4,13}$

Çalışmada, intörn hekimlerin çoğunluğunun kendilerini temel tıbbi becerileri yerine getirmek için gerekli yeterliklere sahip hissettikleri görülmüştür. Ülkemizde yapılan farklı çalışmalarda, intörn hekimler, özellikle temel tıbbi beceriler ve cerrahi uygulamalarda olmak üzere pratik ve/veya teorik konularda kendilerini yetersiz bulduklarını bu nedenle kaygı düzeylerinin yüksek olduğunu belirtmişlerdir. ${ }^{14-16}$

Hekimlik mesleğinin en önemli yeterliklerinden olan öykü alma ve sistemik muayene hastalığın tanısını koyabilmek için mutlaka yapılması gereken temel becerilerdir. Sadece hasta takibi yapılan son sinif tıp eğitiminde, öğrencilerin mezuniyet öncesi genel 
fizik muayene becerilerini yüksek oranda kazanmış olmaları beklenmektedir Çalışmamızda katılımcıların \%84,6'sı COVID-19'lu bir hastadan öykü alabileceğini, \%65'i COVID-19 olduğu düşünülen bir hastaya sistemik fizik muayene yapabileceğini belirtmiştir. Çalışmaya göre bulaşıcı bir hastalığı olan hastanın sistemik muayenesinin nasıl yapılması gerektiği konusunda öğrencilerin eğitim ihtiyacının olduğu düşünülmüştür. Farklı üniversitelerde yap1lan çalışmalarda intörn hekimlerin çoğunluğunun genel fizik muayene becerilerinde kendilerini yeterli gördükleri belirtilmiştir. ${ }^{15,17}$ Çalışmamızdaki oranlar Günay'ın ${ }^{18}$ çalışmasındaki oranlara benzer bulunmuştur.

Mezun hekim adaylarının UÇEP içeriğinde yer alan sağlık hizmeti ilişkili enfeksiyonları engelleyici önlemleri alabilme, toplu yaşam alanlarında enfeksiyonları engelleyici önlemleri alma, toplumda bulaşıcı hastalıklarla mücadele edebilme, toplumda sağlıkla ilgili sorunları epidemiyolojik yöntemler kullanarak saptayabilme ve çözüm yollarını ortaya koyabilme konularında yeterli olması beklenmektedir. ${ }^{9}$ Çalışmada intörnlerin yaklaşık yarısı temas, damlacık, solunum izolasyonunu ve nasıl uygulandığını bilmediklerini belirtmişlerdir. Bu durum hizmet sunumunda bulaşıcı hastalıklar açısından büyük risk oluşturabilecektir. Atılgan ve ark.'nın ${ }^{17}$ çalışmasında intörn hekimlerin yarısından fazlası enfeksiyonu engelleyici önlemleri alma, bulaşıcı hastalıklarla mücadele edebilme ve epidemiyolojik verileri kullanarak çözüm yollarını bulabilme konusunda eğitim almadıklarını bildirmişlerdir. Karabay ve ark.'nın ${ }^{19}$ intörn hekimlerin bilgi ve tutumlarını değerlendirmek için yaptıkları çalışmada öğrencilerin izolasyon yöntemleri hakkında bilgilerinin oldukça az olduğu bildirilmiş, bu da eğitim programında bu konuya yer verilmemesine bağlanmıştır. Bu konuda mevcut olan bilgi eksikliği, intörn hekimlerin hastalığı hastalarına, çevresine yayma riskini getirdiği gibi topluma ve diğer sağlık çalışanlarına yanlış bilgi ve mesajlar vermesine de neden olabilecektir. Araştırmada intörn hekimlerin hemen hemen hepsi el yıkama ve alkollü el dezenfektanı kullanma kurallarını bildiğini belirtmiştir. Bu bulgu oldukça sevindiricidir. Çünkü özellikle sağlık bakımı öncesi ve sonrası yapılan el temizliği bulaşıcı hastalıkların yayılmasını önlemede en önemli faktörlerden birisidir. ${ }^{20}$ Çalışmamıza benzer şekilde Karabay ve ark.'nın ${ }^{19}$ çalışmasında intörn hekimlerin el yıkama konusunda bilgilerinin oldukça yeterli olduğu vurgulanmıştır.

Çalışmamızda intörn hekimlerin büyük kısmının dezenfeksiyon, sterilizasyon ve temizlik konularında yeterli bilgiye sahip olmadıkları görülmüştür. İntörn hekimlerin \%49,6's1 stetoskop, tansiyon aleti temizliği-dezenfeksiyonunu, \%27,4’ü alet ve ortamlar için uygun olan dezenfeksiyon, sterilizasyon yöntemlerini bildiğini, \%23,9'u temizlik personeline anlatabilmek ve kontrolünü yapabilmek için hasta odalarının ve eşyalarının nasıl temizlendiğini, \%17,7'si çarşaf, battaniye temizliği gibi hijyen prosedürlerini bildiğini ifade etmiştir. $\mathrm{Bu}$ verilerin ve farklı çalışmaların 1 şı̆̆ında tıp eğitiminde daha çok hastalıklar üzerinde yoğunlaşmasından dolayı, öğrencilerin bir sağlık kuruluşunun en önemli unsurlarından olan dezenfeksiyon, sterilizasyon ve hijyen konularında eksik bilgiler ile mezun oldukları düşünülmüştür. ${ }^{17,19}$

Bu çalışmada intörn hekimlerin büyük kısmı idrar sondası, nazogastrik sonda takma, tansiyon ölçme, EKG çekip yorumlama, kardiyopulmoner resusitasyon, moniterizasyon takibi, kan şekeri ölçümü, ambu uygulaması gibi gerek acil gerekse servis hastası takibinde gerekli olabilecek tıbbi beceriler konusunda kendilerini yeterli bulmaktadir. Literatürde intörn hekimlerin acil uygulamalar konusunda kendilerini yeterli hissetmedikleri bu nedenle acil hasta takibi açısından kaygılarının yüksek olduğu bildirilmiştir. ${ }^{15,17}$

Çalışmamızda öğrencilerin yarısından daha fazlası hastaya entübasyon yapamayacağını bildirmiştir. Tıp eğitimi sırasında entübasyon becerileri klinik öncesi dönemde genellikle maket üzerinde simüle edilerek, klinik dönemde ise anestezi klinik pratik uygulamasinda hasta uyuduktan sonra uygulatılabilmektedir. Arrest olmuş gerçek hastaya acil müdahale gerektiğinden entübasyonu doktor ve teknik tıbbi personel yapmakta, öğrencilerin bu işlemi izleyerek öğrenmeleri dişında bir şansları kalmamaktadır. Literatür incelemelerinde tıp fakültesi öğrencilerinin sıklıkla uyguladıkları tıbbi becerileri yapabilme konusunda daha iyi oldukları, yapmadıkları veya çok az yaptıkları becerilerde kendilerini iyi bulmadıkları bildirilmiştir. ${ }^{18}$

Çalışmada katılımcıların tıbbi beceriler içinde en az yapabildikleri uygulamaların hastadan kan alma, damar yolu açma, flakon, ampul, serum seti hazırlama, damar yolu açarak mayi ve ilaç tedavisi uygulamaları gibi enjeksiyon uygulamalarının olduğu görülmüştür. Hekim adaylarının mesleki hayatta sıklıkla karşılaşacakları bu tıbbi becerilerde daha az yeterliğe sahip olmalarının nedeni, enjeksiyon uygulamalarını görevlerinden dolayı hemşire ve teknik tıbbi personelin yapmasına, öğrencilerin bu becerileri asli 
görevleri olarak üstlenmemesine bağlanmıştır. ${ }^{21}$ Özçelik ve ark.nın ${ }^{22}$ çalışmasında intörn hekimlerin yaklaşık üçte ikisinin kendisini enjeksiyon becerileri konusunda yeterli hissetmediği bildirilmiştir. Atılgan ve ark.'nın ${ }^{17}$ intörn hekimlerin ulusal çekirdek eğitim programında yer alan temel hekimlik uygulamalarını yapma ve yapabileceklerine dair inanç durumlarını belirlemek için yaptıkları bir çalışmada katılımcıların büyük kısmı enjeksiyon uygulamalarını eğitimleri sırasında yaptığını ve mesleki hayatında yapabileceğini bildirmiştir.

Bu çalışmada COVID-19 hastalarının tanısını koyup takibini yapabilmek için intörn hekimlerin \%76,9'u akciğer grafisi yorumlayabileceğini ifade etmiştir. Göçgeldi ve ark.nın ${ }^{23}$ çalışmasına katılan intörn hekimlerin tamamı akciğer grafisi yorumladıklarını bildirmişlerdir. Çalışmamıza benzer şekilde Atılgan ve ark.nın ${ }^{17}$ çalışmasında intörn hekimlerin \%78'i direkt radyografileri okuyup değerlendirebileceğini ifade etmiştir.

COVID-19'un tanı ve ayırıcı tanısını yapabilmek için mikrobiyolojik örneklerin çalışılması gerekmektedir. Bu maksatla intörn hekimlere bazı kültür alma yöntemlerini bilip bilmedikleri sorulmuştur. Kat1lımcıların yarısına yakını boğaz, nazofarengeal kültür, \%60,7'si kan kültürü, \%73,5'i idrar kültürü alabileceğini ifade etmiştir. Atılgan ve ark.nın ${ }^{17}$ çalışmasında öğrencilerin \%88,5'i, Göçgeldi ve ark.nın çalışmasında ${ }^{23}$ ise $\% 63,2$ 'si genel olarak kültür örneklerini alabileceğini bildirmiştir. Ancak bu iki çalışmada da kültür alma yöntemleri ayrı ayrı sorulmadığı için hangi kültür alma yöntemini daha iyi yapabilecekleri konusunda bir veriye ulaşılamamıştir.

Araştırmada intörn hekimlerin maske, eldiven, bone gibi sıklıkla kullanılan kişisel koruyucu ekipmanları giyme ve çıkarma kurallarını bildiği görülürken, sıçrayıcı vücut sekresyonlarına yönelik işlemler yapıldığında ve özellikle salgın dönemlerinde giyilmesi daha çok vurgulanan koruyucu önlük, koruyucu gözlük, yüz siperi, ayak koruyucu, tulum gibi özellikli kişisel koruyucu ekipmanları giyme ve çıkarma kurallarını bilmedikleri görülmüştür. Bulaşıcı hastalıkların kişinin kendisine ve çevresine yayılmasını önlemek için kişisel tıbbi koruyucu ekipmanların kullanımı oldukça hayati öneme sahiptir. Doktor ve sağlık ekibinde bu ekipmanların kullanımının tutum haline getirilmesi için ekipmanların nasıl ve hangi durumlarda kullanılması gerektiğini vurgulayan eğitimlerin mezuniyet öncesi eğitimde sıklıkla verilmesi çok önemlidir. Nitekim literatürde bilgi düzeyi artan tıp öğrencisi ve sağlık çalışanlarının tıbbi koruyucu ekipman kullanımı konusunda olumlu tutum geliştirdikleri bildirilmektedir. $^{24,25}$

Bu çalışmanın bazı sınırlılıkları mevcuttur. Tek bir fakültenin intörn hekimleri arasında yapılan bu araştırma sonuçları diğer fakülteler için genelleştirilemez. Bu nedenle UÇEP'de yer alan yeterlikler konusunda her üniversitenin kendi verisini elde etmesi uygun olacaktır.

Bu çalışmada fakültemiz intörn hekimlerinin büyük kısmının kendilerini COVID-19 hastasında gerekebilecek temel tıbbi beceri ve bilgiler açısından yeterli buldukları, mezuniyetlerinin gecikmemesi ve COVID-19 olgularını takip etmeyi öğrenmek için eğitimlerinin devam etmesini istedikleri görülmüştür. Literatür ile uyumlu bir şekilde çalışmada intörn hekimlerin büyük kısmı bulaşıcı hastalıklardan korunma ve önleme yöntemleri konusunda yeterli bilgiye sahip olmadıklarını belirtmişlerdir. Bu sonuçlar ve literatür araştırmasına dayanarak tıp fakültesi öğrencilerinin eğitiminde bulaşıcı hastalıklar, korunma ve önleme yöntemleri konusunda pratik eğitim uygulamalarının artırılması gerektiği sonucuna ulaşılmıştır.

Etik Komite Onayı: Fırat Üniversitesi Tıp Fakültesi Etik Kurulu'undan etik onayı alınmıştır (Tarih:29.04.2020, karar no: 2020/07-02).

Çıkar Çatışması: Yazarlar çıkar çatışması bildirmemektedir.

Yazar Katkıları: Fikir - TÖK; Denetleme- TÖK; Malzemeler - TÖK; Veri toplanması ve/veya işlemesi- TÖK; Analiz ve/veya yorum - TÖK; Yazıyı yazan - TÖK.

Hakem Değerlendirmesi: Dış bağımsız.

\section{KAYNAKLAR}

1. Guo YR, Cao QD , Hong ZS et al. The origin, transmission and clinical therapies on coronavirus disease 2019 (COVID-19) outbreak- an update on the status. Mil Med Res. 2020;7 (1):11. doi:10.1186/s40779-020-00240-0

2. DeWitt DE. Fighting COVID-19: Enabling graduating students to start internship early at their own medical school. Ann Intern Med. 2020;173(2):143-144. doi:10.7326/M20-1262

3. Fraher EP, Pittman P, Frogner BK et al. Ensuring and sustaining a pandemic workforce. N Engl J Med. 2020;382(23):2181-2183. doi:10.1056/ NEJMp2006376

4. Mahase E. Covid-19: Medical students to be employed by NHS as part of epidemic re- 
sponse. BMJ. 2020;368:m1156. doi:10.1136/ bmj.m1156

5. Whelan A, Prescott J, Young G, Catanese VM, McKinney R. Guidance on medical students' clinical participation: effective immediately. Association of American Medical Colleges (AAMC). https://lcme.org/wp-content/uploads/ filebase/March-17-2020-Guidance-on-MediicalStudents-Clinical-Participation.pdf Accessed May 02, 2020.

6. Whelan A, Prescott J, Young G, Catanese VM, Mc Kinney R. Guidance on medical students' participation in direct patient contact activities: principles and guidelines. Association of American Medical Colleges (AAMC). https:// www.aamc.org/system/files/2020-03/mededMarch-30-Interim-Guidance-on-MedicalStudents-Clinical-Participation_0.pdf . Accessed May 02, 2020.

7. Lacobucci G. Covid-19: Medical schools are urged to fast-track final year students. BMJ. 2020;368:m1064. doi:10.1136/bmj.m1064

8. Medical Schools Council. Advice from medical schools council to UK medical schools on actions surrounding covid-19. https:// www.medschools.ac.uk/media/2620/msc-covid19-advice-for-uk-medical-schools.pdf. Accessed May 02, 2020.

9. Yüksek Öğretim Kurumu. Mezuniyet Öncesi Tıp Eğitimi - Ulusal Çekirdek Eğitim Programı 2020. https://www.yok.gov.tr/Documents/Kurumsal/ egitim_ogretim_dairesi/Ulusal-cekirdek-egitimiprogramlari/mezuniyet-oncesi-tip-egitimicekirdek-egitimi-programi.pdf. Erişim tarihi 4 Nisan 2021.

10. Kang L, Li Y, Hu S et al. The mental health of medical workers in Wuhan, China dealing with the 2019 novel coronavirus. Lancet Psychiatry. 2020;7(3):14. doi:10.1016/S2215-0366(20)30047 -X

11. Cao W, Fang Z, Hou G et al. The psychological impact of the COVID-19 epidemic on college students in China. Psychiatry Res. 2020;287. doi:10.1016/j.psychres.2020.112934

12. Loh LC, Ali AM, Ang TH, Chelliah A. Impact of a spreading epidemic on medical students. MJMS. 2020:13(2);30-36.

13. Harvey A. Covid-19: Medical students should not work outside their competency, says BMA. BMJ. 2020;368:m1197. doi:10.1136/bmj.m1 197

14. Özvariş, S, Sönmez, R, Sayek, I. Assessment of knowledge and skills in primary health care ser- vices: senior medical students' selfevaluation. Teach Learn Med. 2004;16(1):34-38. doi:10.1207/s15328015tlm1601_8

15. Yalçınoğlu N, Kayı İ, Işık ŞT, et al. İstanbul Üniversitesi İstanbul Tıp Fakültesi son sınıf öğrencilerinin tıp eğitimi ile ilgili görüşleri. İst Tıp Fak Derg. 2012;75:41-45.

16. Kaygusuz TÖ, Erensoy A. Cinsiyete Göre Tıp Eğitimi ve Son Sınıf Tıp Öğrencilerinin Mesleki Beklentileri Konusundaki Görüşler. F.Ü.Sağ.Bil.Tıp.Derg. 2019;33(3):127-135.

17. Atılgan B, Temizayak F, Çağıran $\mathrm{T}$ et al. Tıp fakültesi son sınıf öğrencilerinin Hacettepe Üniversitesi Tıp Fakültesi tıp becerileri eğitimine ilişkin görüşleri. Tıp Eğitimi Dünyası. 2020;19 (57):5-25.

18. Günay, O. Erciyes Üniversitesi Tıp Fakültesi son sınıf öğrencilerinin tıp eğitimi hakkındaki düşünceleri Tıp Eğitimi Dünyası. 2002;7:49-55.

19. Karabay O, Yarımbaş A, Akcakaya U, Öğütlü A. Tıp fakültesi son sınıf öğrencilerinde izolasyon önlemleri konusunda bilgi ve tutumlarının değerlendirilmesi. OTJHS. 2018;3(2):50-55.

20. Accardi R, Castaldi S, Marzullo A, RonchiS, Laquintana D, Lusignani M. Prevention of healthcare associated infections: a descriptive study. Ann Ig. 2017;29:101-115.

21. Hemşirelik yönetmeliği. Resmî gazete tarihi: 08.03.2010 Resmî gazete sayısı: 27515. Erişim tarihi 04 Mayıs 2020.

22.Özçelik M, Solakoğlu Z. Tıp fakültesi 6.sınıf öğrencilerinin enjeksiyon ve cerrahi dikiş uygulamaları konusundaki kazanımlarının değerlendirilmesi. İst T1p Fak Derg. 2014;77:1-7.

23. Göçgeldi E, İstanbulluoğlu H, Uçar M, Yaren H, Ceylan S, Koçak N. Tıp fakültesi 5. ve 6. sınıf ögrencilerinin tıp eğitimleri süresince pratik uygulama yapabilme durumunun araştırılması. Gülhane Tip Derg. 2011;53:107-113.

24. Modi PD, Nair G, Uppe A et al. COVID-19 awareness among healthcare students and professionals in Mumbai Metropolitan Region: A Questionnaire-Based Survey. Cureus. 2020;12 (4):e7514.

25. Khan MU, Shah S, Ahmad A, Fatokun O. Knowledge and attitude of healthcare workers about middle east respiratory syndrome in multispecialty hospitals of Qassim, Saudi Arabia. BMC Public Health. 2014;14:1281. 